\title{
Coagulation in Device or Device Ingredient
}

National Cancer Institute

\section{Source}

National Cancer Institute. Coagulation in Device or Device Ingredient. NCI Thesaurus.

Code C63274.

Problem associated with the undesired characterization of cong ealing, solidifying, thickening, curdling. 